\title{
Correspondence
}

CHI. \& WTO ReV. 2017:1; 163-168

http://dx.doi.org/10.14330/cwr.2017.3.1.08

pISSN 2383-8221 • elSSN 2384-4388

China and WTO Review

\section{Connecting the Belt and Road Initiative to the Suez Economic and Trade Cooperation Zone Development}

\author{
Prince-Arnaud Adiko*
}

\section{Overview: Chinese Investments in Egypt}

The Arab Republic of Egypt established diplomatic relations with the People's Republic of China on May 30, $1956^{1}$ as the first African State. ${ }^{2}$ At the time, China extended an aid commitment of USD 4.7 million to the Egyptian government. ${ }^{3}$ China also firmly backed the Egyptian stance on the Suez Canal and its struggle against colonial interferences. ${ }^{4}$

On April 21, 1994, China and Egypt signed a bilateral investment treaty. ${ }^{5}$ This treaty aimed at encouraging and protecting reciprocal investments on the basis of a mutual win-win cooperation. Their cooperation was upgraded to a comprehensive strategic partnership on December 23, 2014, ${ }^{6}$ signed by Egyptian President Abdel Fattah Al-Sisi and his Chinese counterpart Xi Jinping. President Xi then announced a two-state interdisciplinary cooperation agreement for five years. This comprehensive strategic partnership was actually initiated by Al-Sisi's visits to China in December 2014 and September 2015, respectively. ${ }^{7}$

With Egypt increasingly turning toward China, it would have more opportunities to seek support from China in order to recover from its economic recession. Both have agreed to boost mutual cooperation. ${ }^{8}$

In 2016, meanwhile, Egyptian Minister of Investment Dalia Khorshid stated that China ranked the 23rd largest investor in Egypt. ${ }^{9}$ Its investment amount was estimated at about USD 500 million. ${ }^{10}$ Because China is rapidly increasing its

\footnotetext{
* African Correspondent of China and WTO Review. LL.M. (Dongguk U.). The author may be contacted at: princeadik012@gmail.com
} 
investments in Egypt, it could be a top ten in the near future. One of the major projects in this course is to develop the China-Egypt Suez Economic and Trade Cooperation Zone (hereinafter Suez Development Project). China's investment for the Suez Development Project is estimated at USD 4 billion under the Belt and Road Initiative. ${ }^{11}$

\section{The Belt and Road Initiative and the Suez Economic and Trade Cooperation Zone}

The Belt and Road Initiative is composed of the Silk Road Economic Belt (Belt) and the 21st Century Maritime Silk Road (Road). Both concepts were adopted at the Third Plenum of the 18th Chinese Communist Party Congress in November 2013 and published in the Chinese Government's Work Report in March 2014 . $^{12}$ The Belt and Road Initiative aims to revive the ancient trade routes between Asia and Europe. More than 60 countries are involved in this Initiative. ${ }^{13}$ A major goal is to achieve policy co-ordination between the nations across the Belt and Road.

\section{Figure 1: Belt and Road Initiative ${ }^{14}$}

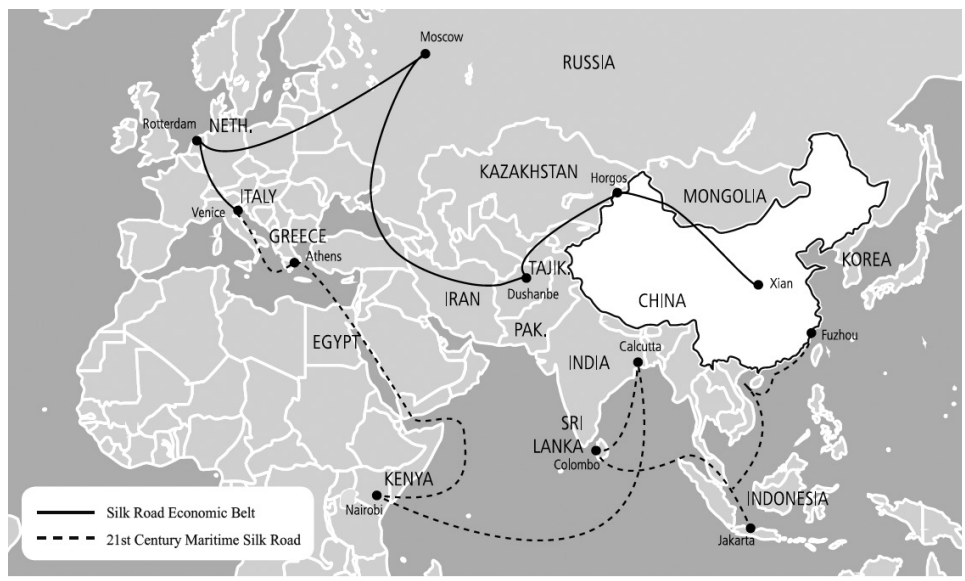

The Suez Development Project was suggested in the context of the Belt and Road Initiative by the Chinese government. ${ }^{15}$ China might consider the economic and political circumstances along the Suez Canal as a great potential. The Suez Canal 
is an artificial sea-level waterway running north to south across the Isthmus of the Suez in Egypt, linking the Mediterranean Sea and the Red Sea. The waterway separates the African continent from Asia, and provides the shortest maritime route between Europe, and the regions around the Indian and western Pacific oceans. It is one of the world's most heavily used shipping lanes. Roughly 10 percent of the world's merchandise and 20 percent of all ships pass through the Suez Canal. ${ }^{16}$

\section{Legal Ground}

There are the following three legal bases for the Suez Development Project. They were signed in January 2016 by President Abdel Fattah El Sisi and President Xi Jinping.

A. MoU on the Silk Road Economic Belt and the 21st Century Maritime Silk Road The MoU provides that China and Egypt agree to expand cooperation under the Belt and Road Initiative. This way, the two countries must work to make Egypt become a pivot of the Belt and Road Initiative. ${ }^{17}$

B. Agreement on Economic and Trade Cooperation at the Suez Canal Economic Zone between the General Authority for the Suez Canal Economic Zone and Chinese Commerce Ministry

The Agreement aims to develop the China-Egypt Suez Economic and Trade Cooperation Zone by encouraging Chinese companies to invest in the zone and other places, especially those from China's competitive sectors such as textile and steel. ${ }^{18}$

C. MoU between Suez Canal Economic Zone and the Chinese National Development and Reform Commission for planning the Suez Canal Corridor ${ }^{19}$ This MoU allows for the expansion of the Suez Development Project to be completed in 10 years. $^{20}$

\section{Economic Benefits of the Suez Development Project}

Highlighting the benefits for Egypt in the increased economic cooperation with 
China, President Xi said in a speech that the planned expansion of the Suez Economic and Trade Cooperation Zone would create more than 10,000 jobs for Egypt. According to the Chinese company in charge of the construction, the expansion project will take 10 years to complete and involve a total investment of USD230 million. ${ }^{21}$

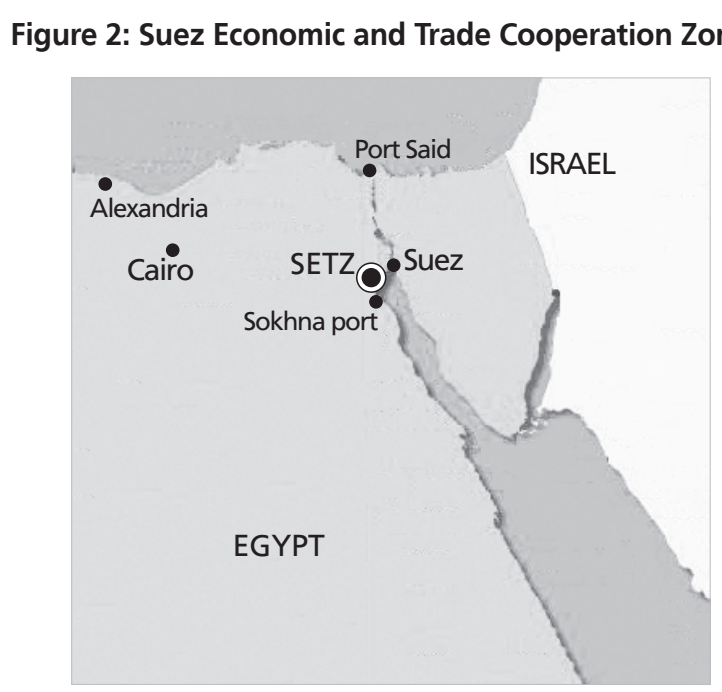

The Suez Economic and Trade Cooperation Zone is located in the Northwest Special Economic Zone of Gulf of Suez, adjacent to Suez Canal. With a planned area of $10 \mathrm{~km}^{2}$, it contains a starting area $\left(1.34 \mathrm{~km}^{2}\right)$ and an expansion area $(6$ $\mathrm{km}^{2}$ ), which aims to build a good platform for Chinese enterprises to invest in Egypt. ${ }^{23}$ It is implemented and operated by the Tianjin Economic Development Area ("TEDA") under the auspices of the Chinese and Egyptian Governments. The Egypt-TEDA Investment Co., founded in 2008 in order to develop the zone with a total investment of USD 100 million, ${ }^{24}$ is taking the lead for the investment, development, construction, management and operation of the Zone. ${ }^{25}$

\section{Conclusion}

For more than one hundred years, the Suez Canal has linked Asia with Africa and Europe. Its connection with the China's Belt and Road Initiative will be a turning 
point in the Canal's history. As China invests in the Belt and Road Initiative area, the Suez Economic and Trade Cooperation Zone Development Project will undoubtedly be a major plan benefiting not only Egypt's economy, but also China and the rest of the world.

\section{REFERENCES}

1. See China-Egypt Relations, available at http://www.china.org.cn/english/features/ phfnt/85089.htm (last visited on Feb. 9, 2017).

2. See The History of Sino-Africa Relations, available at https://sites.google.com/site/ chinapolicyinfocus/china-s-return-to-africa/the-history-of-sino-africa-relations (last visited on Feb. 9, 2017).

3. S. Fernando, Chronology of China-Africa Relations, available at http://www.kdu.ac.lk/ department-of-strategic-studies/images/publications/Chronology\%20of\%20China-Africa \%20Relations.pdf (last visited on Feb. 9, 2017).

4. See Chronology of China-Africa relations, China DAILy, May 5, 2014, available at http:// www.chinadaily.com.cn/world/2014livisitafrica/2014-05/05/content_17483508.htm (last visited on Feb. 9, 2017).

5. See Agreement between the Arab Republic of Egypt and the Government of the People's Republic of China concerning the encouragement and reciprocal Protection of Investments, available at $\mathrm{http}: / /$ investmentpolicyhub.unctad.org/Download/TreatyFile/730 (last visited on Feb. 9, 2017).

6. See China, Egypt elevate bilateral ties to comprehensive strategic partnership, XINHUANET, available at http://news.xinhuanet.com/english/china/2014-12/23/c_133874597.htm (last visited on Feb. 9, 2017).

7. Shaimaa Al-Aees \& Ahmed Adly, Chinese finance institutions immerse into Egypt's economy, pump dollars into market, available at http://www.dailynewsegypt.com/2016/09/01/chinesefinance-institutions-immerse-egypts-economy-pump-dollars-market (last visited on Feb.9, 2017).

8. See China, Egypt agree to boost cooperation under Belt and Road Initiative, XINHUAnET, available at $\mathrm{http}: / /$ news.xinhuanet.com/english/2016-01/22/c_135033384.htm (last visited on Feb. 9, 2017).

9. A. Fakhry, Egypt, China sign agreement to research and execute 18 projects, DAILY NEWS EGYPT, July 12, 2016, available at http://www.dailynewsegypt.com/2016/07/12/egypt-chinasign-agreement-research-execute-18-projects (last visited on Feb. 9, 2017).

10. See Egypt turning towards to China for investment, African Bus. MaG., available at http:// africanbusinessmagazine.com/region/north-africa/egypt-turning-towards-china-investment 
(last visited on Feb. 9, 2017).

11. S. Tiezzi, China's Egypt Opportunity, available at http://thediplomat.com/2014/12/chinasegypt-opportunity (last visited on Feb. 9, 2017).

12. Enright, Scott \& Associates, One Belt One Road: Insight for Finland, Team Finland Future Watch Report, Jan. 2016, available at https://www.tekes.fi/globalassets/julkaisut/future watch_report_one_belt_one_road_insights_for_finland.pdf (last visited on Feb. 9, 2017).

13. A. Viehe, A. Gunasekaran \& H. Downing, Understanding China's Belt and Road Initiative, available at https:/www.americanprogress.org/issues/security/reports/2015/09/22/121628/ understanding-chinas-belt-and-road-initiative (last visited on Feb. 9, 2017).

14. Bomin Ko, Uneasy Days of Push-and-Pull between China and the WTO: Recent Issues of China in the WTO, 1 CHINA \& WTO Rev. 114, Figure 1 (2015).

15. See Broad prospect for China-Egypt economic and trade cooperation, CHINA DAILY, JAN. 22, 2016, available at http:/www.chinadaily.com.cn/world/2016xivisitmiddleeast/2016-01/22/ content_23204973.htm (last visited on Feb. 12, 2017).

16. S. He, Belt-Road initiatives to benefit from 'new' Suez Canal, China Daily, Aug. 7, 2015, available at $\mathrm{http} / / / \mathrm{www} . c h i n a d a i l y a s i a . c o m /$ nation/2015-08/07/content_15301457.html (last visited on Feb. 9, 2017).

17. See China, Egypt agree to boost cooperation under Belt and Road Initiative, XINHUANET, Jan. 22, 2016, available at http://www.chinadaily.com.cn/world/2016xivisitmiddleea st/2016-01/22/content_23195839.htm (last visited on Feb. 11, 2017).

18. Id.

19. See Egypt, China Presidents Attend Signing of 21 Agreements, available at http://allafrica. com/stories/201601240261.html_(last visited on Feb.9, 2017)

20. See Expansion of Sino-Egyptian economic zone to start soon, XINHUANET, Jan. 20, 2016, available at http://news.xinhuanet.com/english/2016-01/20/c_135028852.htm (last visited on Feb. 12, 2017).

21. S. Tiezzi , Xi's Visit Cements Egypt's Place on the 'Belt and Road,' Diplomat, Jan. 22, 2016, available at http://thediplomat.com/2016/01/xis-visit-cements-egypts-place-on-the-belt-androad (last visited on Feb. 11, 2017).

22. From desert to build economic and trade cooperation zones in Africa 从荒漠到都市: 在非洲建设 经贸合作区纪实, available at http://blog.ifeng.com/article/40060961.html (last visited on Feb. 11, 2017).

23. See Egypt TEDA, available at https://www.linkedin.com/company/egypt-teda (last visited on Feb. 12, 2017).

24. See China's TEDA to implement two projects in Gulf of Suez with $\$ 410$ mln-investments, Aug.17, 2016, available at https://projects.zawya.com/Chinas_TEDA_to_implement_two_ projects_in_Gulf_of_Suez_with_410m_investments/story/ZAWYA20160818055405 (last visited on Feb. 12, 2017).

25. See Suez Economic \& Trade Cooperation Zone, available at http://eg2.mofcom.gov.cn/ article/biography/201204/20120408090576.shtml (last visited on Feb. 12, 2017). 